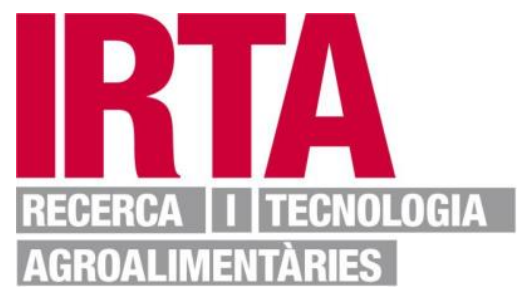

This is the peer reviewed version of the following article: Mónica Ojeda, Iñaki Etaio, Luis Guerrero, M a Pilar Fernández-Gil. Does consumer liking fit the sensory quality assessed by trained panelists in traditional food products? A study on PDO Idiazabal cheese. https:/ / doi.org/ 10.1111/joss.12318. Wiley, which has been publishedin final form at https://doi.org/10.1111/joss.12318. This article may be used fornon-commercial purposes in accordance with Wiley Terms and Conditions for Use ofSelf-Archived Versions 


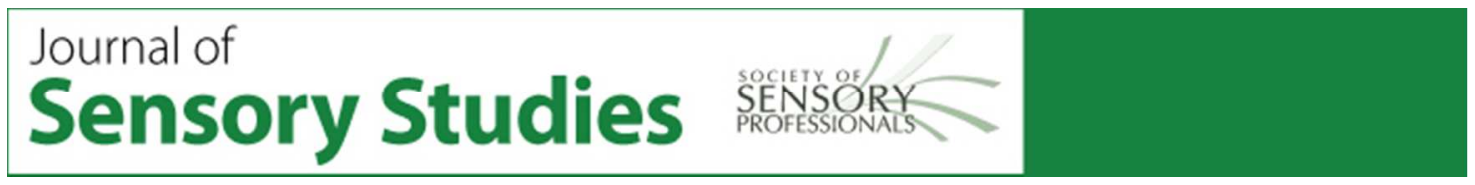

\section{DOES CONSUMER LIKING FIT THE SENSORY QUALITY ASSESSED BY TRAINED PANELISTS IN TRADITIONAL FOOD PRODUCTS? A STUDY ON PDO IDIAZABAL CHEESE}

\begin{tabular}{|c|c|}
\hline Journal: & Journal of Sensory Studies \\
\hline Manuscript ID & JOSS-OA-17-0100.R1 \\
\hline Wiley - Manuscript type: & Original Article \\
\hline Date Submitted by the Author: & $n / a$ \\
\hline Complete List of Authors: & $\begin{array}{l}\text { Ojeda Atxiaga, Monica; Laboratorio de Análisis Sensorial Euskal Herriko } \\
\text { Unibertsitatea (LASEHU). Universidad del País Vasco / Euskal Herriko } \\
\text { Unibertsitatea (UPV/EHU). Centro de investigación Lascaray Ikergunea. } \\
\text { Etaio Alonso, Iñaki; Laboratorio de Análisis Sensorial Euskal Herriko } \\
\text { Unibertsitatea (LASEHU). Universidad del País Vasco / Euskal Herriko } \\
\text { Unibertsitatea (UPV/EHU). Centro de investigación Lascaray Ikergunea.; } \\
\text { Lactiker (Calidad y seguridad de alimentos de origen animal). Universidad } \\
\text { del País Vasco / Euskal Herriko Unibertsitatea (UPV/EHU). Centro de } \\
\text { investigación Lascaray Ikergunea } \\
\text { Guerrero, Luis; IRTA-Monells, Institut de Recerca i Tecnologia } \\
\text { Agroalimentàries, Food Technology. Finca Camps i Armet. } \\
\text { Fernandez Gil, Ma Pilar; Laboratorio de Análisis Sensorial Euskal Herriko } \\
\text { Unibertsitatea (LASEHU). Universidad del País Vasco/Euskal Herriko } \\
\text { Unibertsitatea. Centro de Investigación Lascaray Ikergunea. } \\
\text { Perez Elortondo, Francisco José; Laboratorio de Análisis Sensorial Euskal } \\
\text { Herriko Unibertsitatea (LASEHU). Universidad del País Vasco / Euskal } \\
\text { Herriko Unibertsitatea (UPV/EHU). Centro de investigación Lascaray } \\
\text { Ikergunea.; Lactiker (Calidad y seguridad de alimentos de origen animal). } \\
\text { Universidad del País Vasco / Euskal Herriko Unibertsitatea (UPV/EHU). } \\
\text { Centro de investigación Lascaray Ikergunea. }\end{array}$ \\
\hline Keywords: & $\begin{array}{l}\text { PDO Idiazabal cheese; sensory quality control; trained panel; consumers' } \\
\text { liking; sensory drivers }\end{array}$ \\
\hline Abstract: & $\begin{array}{l}\text { The aim of this work was to study the degree of agreement between } \\
\text { consumer liking and the sensory quality scored by the trained panel in } \\
\text { charge of the quality control of a traditional product (PDO Idiazabal } \\
\text { cheese). Nine cheeses of different qualities were evaluated by eight trained } \\
\text { assessors and by } 212 \text { consumers from Vitoria-Gasteiz (Basque Country). } \\
\text { Cheese samples were clearly different regarding overall sensory quality } \\
\text { (OSQ) assessed by the trained panel. Regarding consumers, five groups } \\
\text { with different correlation levels with OSQ were identified: "sweet" and } \\
\text { "toasty" were the main sensory drivers leading the liking of the consumers } \\
\text { with a higher positive correlation, whereas some defective characteristics } \\
\text { ("animal", "rancid" and "bitter") were the main drivers for consumers with } \\
\text { higher negative correlation. These results suggest that it would be } \\
\text { interesting for the Regulatory Council to strength the communicational }\end{array}$ \\
\hline
\end{tabular}


strategies among consumers to be able to identify the typical and nontypical (mainly defects) characteristics of this traditional product, especially among those liking defective cheeses.

\section{SCHOLARONE" \\ Manuscripts}


1

2

3

4

5

6

7

8

9

10

DOES CONSUMER LIKING FIT THE SENSORY QUALITY ASSESSED BY TRAINED PANELISTS IN TRADITIONAL FOOD PRODUCTS? A STUDY ON PDO IDIAZABAL CHEESE

\section{Short running title: LIKING AND SENSORY QUALITY IN TRADITIONAL FOODS}

MÓNICA OJEDA ${ }^{1}$, IÑAKI ETAIO ${ }^{1,2}$, LUIS GUERRERO ${ }^{3}, \mathrm{M}^{\mathrm{a}}$ PILAR FERNÁNDEZ-GIL ${ }^{1}$ and FRANCISCO JOSÉ PÉREZ-ELORTONDO ${ }^{1,2, *}$

${ }^{1}$ Laboratorio de Análisis Sensorial Euskal Herriko Unibertsitatea (LASEHU). Departamento de Farmacia y ciencias de los alimentos. Universidad del País Vasco / Euskal Herriko Unibertsitatea (UPV/EHU). Centro de investigación Lascaray Ikergunea, Vitoria-Gasteiz, Spain.

${ }^{2}$ Lactiker (Calidad y seguridad de alimentos de origen animal). Universidad del País Vasco / Euskal Herriko Unibertsitatea (UPV/EHU). Centro de investigación Lascaray Ikergunea, Vitoria-Gasteiz, Spain.

${ }^{3}$ IRTA-Monells, Institut de Recerca i Tecnologia Agroalimentàries, Food Technology. Finca Camps i Armet, Monells, Spain.

* Corresponding author. Tel.: +34 945 013075; fax: +34 945013014.

Email address: franciscojose.perez@ehu.eus (F. J. Pérez-Elortondo). 
19

\section{Abstract}

The aim of this work was to study the degree of agreement between consumer liking and the sensory quality scored by the trained panel in charge of the quality control of a traditional product (PDO Idiazabal cheese). Nine cheeses of different qualities were evaluated by eight trained assessors and by 212 consumers from Vitoria-Gasteiz (Basque Country). Cheese samples were clearly different regarding overall sensory quality (OSQ) assessed by the trained panel. Regarding consumers, five groups with different correlation levels with OSQ were identified: "sweet" and "toasty" were the main sensory drivers leading the liking of the consumers with a higher positive correlation, whereas some defective characteristics ("animal", "rancid" and "bitter") were the main drivers for consumers with higher negative correlation. These results suggest that it would be interesting for the Regulatory Council to strength the communicational strategies among consumers to be able to identify the typical and non-typical (mainly defects) characteristics of this traditional product, especially among those liking defective cheeses.

\section{Practical Applications}

This study gives information about the degree of agreement concerning the sensory quality of a traditional product reached by a trained panel and by consumers' preferences.

The research includes information regarding the sensory characteristics which drive liking among different groups of consumers. These results are of interest for the Regulatory Council of this product to define its marketing polices and consumer-oriented education activities in order to provide information about the specific sensory characteristics of the product. Moreover, it may be interesting for PDO Regulatory Councils and other producers of traditional products in order to be more aware about the possible agreement and/or disagreement between the sensory quality of the product and consumer preferences.

\section{Keywords}

PDO Idiazabal cheese; sensory quality control; trained panel; consumers' liking; sensory drivers. 


\section{Introduction}

The food industry usually focuses on consumer preferences when establishing sensory quality control programs (Muñoz 2002; Pecore and Kellen 2002). However, there are certain traditional food products certified with quality labels where consumers' preferences should have less influence on the sensory quality definition than in the case of conventional foods (Ojeda et al., 2015). This is the case of the food products with PDO (EU 2012), which are expected to present some distinctive sensory characteristics linked to their origin, raw materials and traditional practices (Ballester et al. 2005). Taking into account that an important goal of a PDO is to offer high quality products, it is necessary to define and control objectively their sensory characteristics in order to guarantee their authenticity and those sensory characteristics that differentiate them from similar commercial products (Bertozzi and Panari 1993). As a basis for the certification of the product, sensory quality control of PDO products requires both the development of a specific evaluation method as well as a trained panel to not only guarantee the absence of defects in the product but also to consider the presence of particular sensory characteristics (Endrizzi et al. 2012; Etaio et al. 2010; Etaio et al. 2012).

There are an important number of publications addressing how quality labels affect liking, decisionmaking and willingness to pay by consumers (Grunert and Aachmann 2016). However, references relating consumers' liking with sensory quality scores obtained from trained panels are very scarce. In the case of dairy products, the methodology of the International Dairy Federation (IDF 1997) has been used for grading generic cheeses for commercial purposes (Hersleth et al. 2005; Kraggerud et al. 2012). In this method, three sensory quality parameters (appearance, consistency and flavor) are evaluated by trained panels considering a 1-5 point interval scale where 1 corresponds with the lowest quality and 5 corresponds with the highest quality. In generic extra virgin olive oil, Barbieri et al. (2015) and Predieri et al. (2013) investigated the convergence between consumers' liking and sensory quality obtained by using the European official sensory method (European Community, 2008). In this method the intensity of positive and negative characteristics is evaluated by using a 
10 point continuous scale. There is also a work studying the correlation between the sensory quality scores of coffee from Ethiopia evaluated by an exporter (Ethiopia Commodity Exchange (ECX) cupping center) and the scores from an importer in Europe (EFICO Agency SA), the latter reflecting to some extent the preferences of the European coffee consumers (Worku et al. 2016). In spite of the studies of generic food products mentioned, studies dealing with agreement between consumer likes and sensory quality in specific traditional products have not been found.

PDO Idiazabal cheese is a traditional food product from the Basque Country (in the North of Spain) made with raw ewes' milk of the autochthonous Latxa breed and with a ripening time of at least two months. This product has a very marked cultural, social, economic and environmental background (Pérez Elortondo 1996). The official sensory quality control of this product is carried out by a trained panel in the Sensory Laboratory of the University of the Basque Country (LASEHU), which has been accredited following standard ISO 17025 (ISO, 2005) since 2005. PDO Idiazabal cheese is recognized as a high quality product (it has won many awards in national and international competitions) and it is much appreciated by consumers in the Basque Country. Several publications have dealt with the sensory characterization of PDO Idiazabal cheese (Bárcenas et al. 2001; Ordóñez et al. 1998) and the development of a specific methodology for its official sensory quality control (Ojeda et al. 2015; Pérez Elortondo et al. 2007). However, there is no information about consumer preferences for PDO Idiazabal cheeses with different sensory qualities.

The main objective of this study was to determine if the likes of local consumers matched with the sensory quality of the cheese samples assessed by the official trained panel. Also, this work explores the sensory drivers leading consumers' preferences and the effect of socio-demographic characteristics and objective and subjective knowledge about cheese on liking for this product.

\section{Materials and methods}

\subsection{Sample selection and preparation}

Cheese samples were selected from a set of 88 non-smoked cheeses evaluated from June to July in the context of the official sensory quality control of PDO Idiazabal cheese in LASEHU. Nine 
cheeses were chosen taking into account three different quality levels: three samples from the first quartile (cheeses with the highest quality scores), three samples between percentiles 40 and 60 (cheeses with medium quality scores) and three samples from the four quartile (cheeses with the lowest quality scores).

After checking that the nine cheese producers still kept enough samples from the same batch of the selected cheese, 20 units of each cheese (of around $1.2 \mathrm{~kg}$ ) were collected and stored in the ripening chamber of a cheese farm at $9 \pm 2{ }^{\circ} \mathrm{C}$ until their assessment in October, when they had reached fivesix months of ripening. One week before testing, cheeses were moved to the laboratory and kept in a fridge at $5 \pm 3{ }^{\circ} \mathrm{C}$. The night previous to the analysis, samples were placed in a cellar at $17 \pm 2{ }^{\circ} \mathrm{C}$.

Each cheese was cut into pieces of $1 \mathrm{~cm} \times 1 \mathrm{~cm} \times 5 \mathrm{~cm}$ and served in plastic trays to the assessors (trained assessors or consumers, depending on the trial). Samples were codified with three digits and presented according to a Williams Latin square design, so sample-order associated bias was avoided. Sample temperature was $19 \pm 3{ }^{\circ} \mathrm{C}$ when they were evaluated.

\subsection{Sensory quality evaluation by the trained panel}

Sensory analysis was performed in the Sensory Laboratory of the University of the Basque Country (LASEHU), by eight members (two male and six female, with an average age of 42) of the official trained panel for the sensory quality control of PDO Idiazabal cheese. Selection, training and performance of the assessors took place according to Pérez Elortondo et al. (2007). These assessors have been taking part in the sensory quality control on PDO Idiazabal cheese for more than 10 years, being over 100 the number of samples that each assessor evaluate each year.

The evaluation methodology was the sensory quality control method for PDO Idiazabal cheese certification described by Ojeda et al. (2015). This methodology employs a scorecard including eight sensory parameters: quality related to odor, texture, flavor, persistence, shape, rind, color paste and eyes. The evaluation consists in the identification of sensory characteristics (appropriate, not totally appropriate and defective) for each sensory parameter. According to the characteristics identified and by means of a decision tree, a quality score is given to each parameter in a 1-7 point 
123 discontinuous scale. In this scale, point 7 is the "top" sensory situation where characteristics of 124 typicity are considered, 4-6 range covers not totally appropriate characteristics and 1-3 range covers 125 defective sensory characteristics.

126 For the present study, the analysis was conducted only for odor, texture, flavor and persistence 127 parameters. The evaluation of the nine samples was carried out in two sessions on different days of

128 the same week in order to have two replications. Both sensory characteristics and scores were collected by using FIZZ software $2.40 \mathrm{H}$ (Biosystemes, Couternon, France).

Assessment was carried out in individual booths designed according to the standard ISO 8589 (ISO, 2007). A waiting time of one minute between samples was programmed. Assessors chewed apple and rinsed their mouth with water between samples to eliminate residual sensations.

\subsection{Assessment of liking by consumers}

Two hundred and twelve consumers living in Vitoria-Gasteiz city (Basque Country) participated in this research. They were recruited from previous databases and by using different media (radio, emails, social networking sites and posters on the university campus). Consumers who expressed their willingness to participate were asked about gender, age, region of residence and cheese consumption frequency. Only consumers from Vitoria-Gasteiz with a cheese consumption of at least once a month were recruited, while a balanced distribution regarding gender and age ranges $(18-29,30-44,45-59, \geq 60)$ was also sought.

The consumer study was carried out over 14 sessions of about 45 minutes for four days of the same week. These trials were carried out a week after the sensory analysis by the trained panel so it can be supposed that the effect of further cheese ripening was negligible. Up to sixteen consumers took part in each session evaluating the nine samples in individual booths under white light at $21 \pm 2{ }^{\circ} \mathrm{C}$. No information about the aim of the study was provided to them (they only knew that they were participating in a "cheese study"). Participants were asked to fill in four different questionnaires on paper forms. In the first questionnaire consumers were asked to score the samples for liking on a discontinuous 9-point scale structured as follow: 1-“dislike extremely”, 2-“dislike very much”, 3- 
149

150

151

152

153

154

155

“dislike moderately", 4-“dislike slightly”, 5-“neither like nor dislike”, 6-“like slightly”, 7-“like moderately", 8-“like very much" and 9-“like extremely". Consumers were allowed to taste the cheeses as many times as they wanted, although they were advised not to test the same sample many times to avoid fatigue. Also, they were instructed to have breaks of about one minute between contiguous samples and to chew apple and rinse mouths with water during the break to eliminate residual sensations.

Secondly, consumers were provided with a questionnaire to indicate the level of knowledge about cheese they thought they had (subjective knowledge). A discontinuous 7-point scale structured from "low knowledge" on the left to "high knowledge" on the right was used. For data treatment purposes, a score $\leq 2$ was considered as "low knowledge", from 3 to 5 as "medium knowledge" and $\geq 6$ as "high knowledge". Next, objective knowledge was evaluated by means of ten questions about cultural and technical aspects of cheeses with multiple choice answers (Fig. 1). The questionnaire provided a mark for each consumer from 0 to 100 as a result of assigning 10 points to each right answer. For data treatment purposes, 0 to 29 points was considered as "very low knowledge", 30 to 49 points as "low knowledge" and $\geq 50$ points as "medium - high knowledge". Finally, the fourth questionnaire consisted of questions about socio-demographic characteristics and cheese consumption habits. Upon completing the session, consumers received a gift for their participation.

\subsection{Data analysis}

Overall sensory quality (OSQ) for each sample, session and assessor was calculated by applying the following equation (based on the criteria of the Regulatory Council of PDO Idiazabal cheese as described by Pérez Villarreal et al. (1995)): OSQ = odor quality x $0.20+$ texture quality x $0.25+$ flavor quality x $0.35+$ persistence quality x 0.20 .

To study the possible significative $(P<0.05)$ differences among the sensory quality of the samples different analysis were used. As there was no normality in the distribution of the scores for odor, flavor, texture and persistence, Kruskal-Wallis test was applied (with Dunn's test with Bonferroni's 
175

176

177

178

179

180

181

182

correction to study the differences between pairs of samples). As the distribution for OSQ was normal, a three-way ANOVA was applied for this parameter, with product (cheese), assessor and session as fixed factors and all first order interactions included in the model. Tukey's honest significant difference (HSD) test was used to study the differences between samples.

Regarding consumers' data, a two-way ANOVA was performed on individual liking scores considering product (cheese) as fixed factor and consumer as random effect. Tukey's HSD test was applied to identify pair of products significantly different. In order to check if each consumer individually agreed with the trained panel, Pearson correlation coefficient was calculated considering individual liking scores and OSQ mean scores from the trained panel. Next, consumers were grouped in six categories according to this coefficient $(r \geq 0.7$ high correlation, $0.4 \leq \mathrm{r}<0.7$ medium correlation, $\mathrm{r}<0.4$ low correlation) and its sign (positive or negative). In order to visualize consumer groups' preferences for each of the nine samples in a two-dimensional space, an internal preference mapping was performed on the individual liking data.

In order to study the sensory drivers leading consumers' liking, the citation frequency (CF) of each sensory characteristic by the trained panel was considered. CF was calculated as the number of times (in percentage) that each characteristic was cited for each sample over the total number of times that it could be cited ( 8 assessors $\mathrm{x} 2$ sessions $=16$ times). In order to study differences among products, Cochran's Q test was carried out on sensory characteristics presenting a $\mathrm{CF} \geq 15 \%$ for all the samples considered together or when any of the samples presented a $\mathrm{CF} \geq 25 \%$. A contingency table (cheese samples in rows and sensory characteristics in columns) containing the number of citations of each sensory characteristic by the trained panel for each cheese sample was prepared and a simple correspondence analysis (CA) was carried out. Then, average liking for each cheese sample was modelled for each group of consumers as a function of the first two dimensions of the CA using an external preference mapping. Linear and circular models were tested. In order find the best model, an F-ratio test, with a $25 \%$ of significance level, was used.

All these analysis were run with the XLSTAT statistical software 2011 (Addinsoft, Paris, France). 
201 Finally, Chi-square $\left(\chi^{2}\right)$ test with Yates's correction was applied for finding significant differences $202(P<0.05)$ within each group and among groups for each aspect considered in the four 203 questionnaires (subjective and objective knowledge, socio-demographic aspects and cheese consumption habits). This test was carried out on http://quantpsy.org (Preacher, 2001).

\section{Results and discussion}

\subsection{Consumers' characterization}

Information characterizing consumers from questionnaires two to four is shown in Table 1. 83.5\% of the participants were habitual consumers of cheese $(32.1 \%$ daily or almost daily and $51.4 \%$ once or several times a week). Regarding type of cheese, hard cheese was the most consumed (56.6\% of the participants) followed by semi-hard cheese (30.2\% of the participants). With regard to the origin of the milk for the cheese, the majority of participants $(74.5 \%)$ mostly consumed ewe / goat's milk cheeses. With regard to knowledge about cheese, while $77.4 \%$ of consumers claimed medium subjective knowledge only $17.9 \%$ showed medium-high knowledge according to the third questionnaire.

\subsection{Relationship between sensory quality and consumers' liking}

Mean quality scores and standard deviation from the trained panel for odor, texture, flavor and persistence related quality and for OSQ of the nine cheeses are shown in Table 2, as well as significant differences $(P<0.05)$ among samples. These results confirmed that cheese samples had different sensory qualities. Sample 9 presented significant higher OSQ than samples 1 to 6 . By contrast, OSQ of samples 1 and 2 was significantly lower than the other seven samples. Regarding consumers' liking, there were also significant $(P<0.05)$ differences among cheeses. In the same way as observed for OSQ, sample 9 was significantly more appreciated than samples 1 to 6 . At the same time, liking for samples 1 and 2 was lower than for the other seven samples.

Cheeses with the highest OSQ (cheese 7,8 and 9) had the highest liking scores and cheeses with the lowest OSQ (cheese 1 and 2) were the least appreciated by consumers. When studying individual relationships between liking and OSQ (Table 3), a different pattern of preference was observed 
227

228

among the consumers. The majority of the consumers (77.4\%) presented a positive correlation with the OSQ from the trained panel. On the contrary, there was a minor group of consumers $(22.6 \%)$ with a negative correlation between their liking and the OSQ. Within each group, consumers were grouped in three categories according to Pearson correlation coefficient (low: $r<0.4$; medium: 0.4 $\leq \mathrm{r}<0.7$; high: $\mathrm{r} \geq 0.7$ ). As the number of consumers with high and medium negative correlation was very low, they were gathered in the same group. The distribution of the consumers of the resulting five groups and their preference towards the nine samples can be visualize in Fig. 2. Grupo 1 was composed of 16 consumers who preferred samples 1,3 and to a certain extend sample 2 . Conversely, groups 4 and 5, composed of 52 and 42 consumers respectively, clearly preferred cheeses 7, 8 and 9. Regarding consumers from groups 2 and 3 (32 and 70 respectively), they appear much dispersed across Y-axis of the sensory space, showing a less clear preference toward the samples.

The existence of groups of consumers whose acceptability is not in accordance with sensory quality assessed by a trained panel has been reported in other studies with Norwegian cheeses. Hersleth et al. (2005) found a group of consumers preferring the sample with the lowest quality score. According to these authors, low levels of sensory defects in dairy products may not always be objectionable to consumers. Kraggerud et al. (2012) identified two clusters of consumers $(29.1 \%$ and $34.1 \%$ ) in disagreement with the trained panel scoring sensory quality. These authors interpreted this finding by arguing that a large number of consumers would prefer other sensory characteristics than those present in the evaluated cheeses.

Regarding characterization of the different groups of consumers by Chi-square $\left(\chi^{2}\right)$ test with Yates's correction, a significant $(\mathrm{P}<0.05)$ higher percentage of young consumers (less than 30 years) was observed in group 5 (the group with the higher agreement with the trained panel) (data not shown). No other significant particularities in relation to socio-demographic characteristics, cheese consumption habits and knowledge about cheese were observed among consumers' groups.

\subsection{Sensory characteristics driving consumers' liking}


253

254

255

256

257

258

259

260

261

262

263

264

265

266

267

268

269

270

271

272

273

274

275

276

277

278

Results from Cochran's Q test showed significant differences $(P<0.05)$ among samples for 45 of the 81 characteristics cited by any member of the panel: 9 of odor ( 2 as appropriate characteristic, $\mathrm{AC} ; 5$ as not totally appropriate characteristic, NTAC; and 2 as defective characteristic, DC), 11 of texture (3 AC, 5 NTAC and 3 DC), 16 of flavor (6 AC, 7 NTAC and 3 DC) and 9 of persistence (6 NTAC and 3 DC).

Fig. 3 represents the correspondence analysis performed on the CF for each sensory characteristic in each sample. It explains $62.60 \%$ of the variance of the experimental data $(44.02 \%$ and $18.58 \%$ in the first and second dimension, respectively). In Fig. 4, the external preference map is shown. This map includes the position of vectors indicating the direction of maximum preference for each group of consumers. The distribution of the groups of consumers confirms the existence of two different main patterns, as stated previously (Fig. 2). One pattern is related to group 1 and, to a certain extent, to group 2. The other pattern is related to groups 4 and 5 and, to a lesser degree, to group 3.

The acceptability of groups 4 and 5 was mainly determined by characteristics as "toasty" (odor, flavor and persistence), "sweet" (taste and persistence), “acid” (persistence), "rancid" (flavor), "absence of bitter" (taste) and "no deformation" (texture). With the exception of "absence of bitter" taste they all were not totally appropriate characteristics. It is worth noting that "toasty" and "sweet" characteristics were associated with sample 9. Regarding group 3, drivers of liking are similar to groups 4 and 5 although less noticeable, probably due to the fact that consumers from group 3 were less discriminative (Fig. 2 and Table 3). This finding suggests that consumers of these groups might prefer intense "toasty" and "sweet" cheeses than the characteristic odor defined for PDO Idiazabal cheese.

Conversely, maximum liking for group 1 was mainly oriented towards products 1 and 2. As shown in Fig. 3, the acceptability was determined by "animal" (odor, flavor and persistence), "rancid" (odor, flavor and persistence), "bitter" (flavor and persistence) and the absence of "milky" odor. With the exception of absence of "milky" odor (not totally appropriate characteristic), they all were defective characteristics for PDO Idiazabal cheese. Consumers of group 2 would have similar 
279

sensory drivers, although with a clearer tendency for "animal" character. This fact suggests that these groups of consumers probably like cheese with some "strong" characteristics. The liking toward some characteristics considered as defective could also have a habituation component. Habit is a strong determinant of individual preferences that, in some cases, can explain the preference for defective food products (Guerrero et al. 2009; Guerrero et al. 2012). For example, in a study with virgin olive oils, Guerrero et al. (2012) found that $49.25 \%$ of consumers preferred a sample with “fusty/muddy sediment" defect.

The opposition between the "strong" characteristics mentioned (“animal", "rancid", "bitter") and "mild" characteristics ("toasty" and "sweet") could explain the segmentation into two main groups of consumers. In fact, this division of sensory characteristics observed in this work was to a great extend similar to that reported by Bárcenas et al. (2001) in a study on Spanish ewes' milk cheeses. These authors found the existence of two clearly different groups of sensory terms: on the one hand "strong or very intense sensory characteristics" ("animal", "sharp", "brine", "rennet" and "butyric acid"), and on the other hand, characteristics that could be defined as "mild or soft" ("milky", "toasty", "buttery", "nutty" and "sweet”). Caspia et al. (2006) identified in Cheddar cheeses two groups of sensory characteristics: one group was characterized by "sweet", "buttery" "creamy" and “cooked" opposed to a group characterized by "earthy", "sulfur", "free fatty acid”, “sour", "bitter", "pungent" and "prickle bite".

As previous studies reveled, the preference of consumers for "mild or soft" characteristics appears to be widespread to cheese consumers. Gonzalez Viñas et al. (1999) compared ten commercial Spanish ewe milk cheeses with a survey of 43 students and concluded that this group of young consumers preferred "milder" cheeses to those with very "strong" characteristics. In a study with Cheddar cheeses, Caspia et al. (2006) found that 65\% of consumers liked samples with "buttery", "creamy", "sweet" and "cooked" flavor.

Conversely, there is evidence that bitterness is not a desirable cheese characteristic for some consumers, as reported by several authors (Arcia et al. 2013; Bord et al. 2017; Caspia et al. 2006; 
Young et al. 2004; Zhang et al. 2011). A dislike for "bitter" taste has also been studied in other food products than cheese, such as whole-grain products (Bakke and Vikers 2007), extra virgin olive oils (Barbieri et al. 2015; Delgado and Guinard 2011; Recchia et al. 2012) or green vegetables (Chadwick et al. 2016; Dinnella et al. 2016; Poelman et al. 2017). This fact might be due to bitter perception playing a role in human activities by evoking a defense mechanism to prevent the ingestion of harmful substances (Chandrashekar et al. 2000). Even though there are individuals who like these substances, humans learn to like bitter foods by experience (Garcia-Burgos and Zamora 2015).

With regard to texture characteristics, these play a minor role in influencing consumer liking (Fig. 3 and Fig. 4) compared to odor and flavor. In this sense, Bárcenas et al. (2003) reported that odor characteristics play an important role at the time of defining consumer preference for ewes' milk cheeses. In the study on Cheddar cheese, Caspia et al. (2006) demonstrated that texture could not be used to relate descriptive sensory analysis to consumer acceptance, whereas flavor characteristics fitted well with it. Arcia et al. (2013) showed that differences in flavor dictated the differences in consumers' acceptance of Uruguayan "queso magro" low-fat cheese. Other authors, has also determined that flavor was more a driving force in overall liking of different cheeses (raw milk cheeses) than texture (Liggett et al. 2008; Yates and Drake 2007; Young et al. 2004). However, in a study on PDO Blue-veined cheese, Bord et al. (2017) found that texture characteristics were the key sensory drivers of liking for $48.4 \%$ of consumers. So, the influence of the texture on the consumers' preferences could also be influenced by the kind of cheese.

\section{Conclusions}

The current study showed that in the case of PDO Idiazabal cheese, acceptability of most consumers agreed to a considerable extent with the official sensory quality determined by the official trained panel of the Regulatory Council. In spite of majority of consumers from Vitoria-Gasteiz preferring PDO Idiazabal cheeses with high quality, different liking patterns were found among consumers. Liking of consumers in agreement with the trained panel was mainly driven by "sweet" and 
"toasty" characteristics, whereas tastes of the small group of consumers disagreeing with the trained panel were related to some defective sensory characteristics, such as "animal", "rancid" and "bitter".

Regulatory Council could take advantage of the results of this study to increase the effort to help the consumers to identify the sensory characteristics of this particular product, with special attention to consumers with preferences towards defective cheeses.

Further research should explore if non-local consumers' liking also fits the sensory quality scored by an official trained panel, thus considering the possible cross-cultural influences.

\section{Acknowledgments}

The authors thank the Departamento de Agricultura, Pesca y Alimentación of the Basque Government for funding this work (PA11/07), the consumers and the trained assessors of PDO Idiazabal cheese panel for their participation.

\section{References}

ARCIA, P., CURUTCHET, A., COSTELL, E. and TARREGA, A. 2013. Sensory properties and acceptance of Uruguayan low-fat cheese "queso magro". Dairy Sci. Technol. 93, 151-162.

BAKKE, A. and VICKERS, Z. 2007. Consumer liking of refined and whole wheat breads. Journal of Food Sci. 72 (7), 473-480.

BALLESTER, J., DACREMONT, C., LE FUR, Y. and ETIÉVANT, P. 2005. The role of olfaction in the elaboration and use of the Chardonnay wine concept. Food Qual. Pref. 16 (4), 351-359.

BARBIERI, S., BENDINI, A., VALLI, E. and GALLINA TOSCHI, T. 2015. Do consumers recognize the positive sensorial attributes of extra virgin olive oils related with their composition? A case study on conventional and organic products. J. Food Compos. Anal. 44, 186-195.

BÁRCENAS, P., PÉREZ ELORTONDO, F.J., SALMERÓN, J. and ALBISU, M. 2001. Sensory profile of ewe's milk cheeses. Food Sci. Technol. Int. 7(4), 347-353. 
355

356

357

358

359

360

361

362

363

364

365

366

367

368

369

370

371

372

373

374

375

376

377

378

379

380

BÁRCENAS, P., PÉREZ ELORTONDO, F.J. and ALBISU, M. 2003. Comparison of free choice profiling,direct similarity measurements and hedonic data for ewes' milk cheeses sensory evaluation. Int. Dairy J. 13, 67-77.

BERTOZZI, L. and PANARI, G. 1993. Cheeses with appellation d'origine contrôlée (AOC): Factors that affect quality. Int. Dairy J. 3, 297-312.

BORD, C., GUERINON, D. and LEBECQUE, A. 2017. Heated or raw Blue cheeses: what are the drivers influencing consumer preferences?. Int. J.Food Sci. Technol. 52, 1959-1970.

CASPIA. E.L., COGGINS, P.C., SCHILling, M.W., YOON, Y. and WHITE, C.H. 2006. The relationship between consumer acceptability and descriptive sensory attributes in cheddar cheese. J. Sensory Stud. 21, 112-127.

CHADWICK, M., GAWTHROP, F., MICHELMORE, R.W., WAGSTAFF, C. and METHVEN, L. 2016. Perception of bitterness, sweetness and liking of different genotypes of lettuce. Food Chem. 197, 66-74.

CHANDRASHEKAR, J., MUELLER, K.L., HOON, M.A., ADLER, E., FENG, L.X. and GUO, W. 2000. T2Rs function as bitter taste receptors. Cell 100, 703-711.

DELGADO, C. and GUINARD, J-X. 2011. How do consumer hedonic ratings for extra virgin olive oil relate to quality ratings by experts and descriptive analysis ratings?. Food Qual. Pref. 22, 213225.

DinNella, C., MORIZET, D., MASI, C., CliCERI, D., DEPEZAY, L., APPLETON, K.M., GIBOREAU, A., PÉREZ-CUETO, F.J.A., HARTWELl, H. and MONTELEONE, E. 2016. Sensory determinants of stated liking for vegetable names and actual liking for canned vegetables: A cross-country study among European adolescents. Appetite 107, 339-347.

ENDRIZZI, I., APREA, E., BIASIOLI, F., COROLlARO, M. L., DEMATTÈ, M. L., PENASA, M., BITTANTE, G. and GASPERI, F. 2012. Implementing sensory analysis principles in the quality control of PDO products: a critical evaluation of a real-world case study. J. Sensory Stud. $28,14-24$. 
381

382

383

384

385

386

387

388

389

390

391

392

393

394

395

396

397

398

399

400

401

402

403

404

405

ETAIO, I., ALBISU, M., OJEDA, M., GIL, M.P. F., SALMERÓN, J. and PÉREZ ELORTONDO, F. J. 2010. Sensory quality control for food certification: a case study on wine. Method development. Food Control 21, 533-541.

ETAIO, I., GIL, M.P. F., OJEDA, M., ALBISU, M., SALMERÓN, J. and PÉREZ ELORTONDO, F. J. 2012. Improvement of sensory quality control in PDO products: an example with txakoli white wine from Bizkaia. Food Qual. Pref. 23, 138-147.

EU. 2012. Regulation $n^{\circ} 1151 / 2012$ of the European parliament and of the council of 21 November on quality schemes for agricultural products and foodstuffs. Off. J. Eur. Communities L343/1.

EUROPEAN COMMUNITY. 2008. Commission Regulation No. 640/2008. Amending Regulation No 2568/91/EEC. Off. J. Eur. Communities L178, 11-16.

GARCIA-BURGOS, D. and ZAMORA, M.C. 2015. Exploring the hedonic and incentive properties in preferences for bitter foods via self-reports, facial expressions and instrumental behaviours. Food Qual. Pref. 39, 73-81.

GONZALEZ VIÑAS, M. A., ESTEBAN, E. M. and CABEZAS, L. 1999. Physico- chemical and sensory properties of Spanish ewe milk cheeses and consumer preferences. Milchwissenschaft 54(6), 326-329.

GRUNERT, K. and AACHMANN, K. 2016. Consumer reactions to the use of EU quality labels on food products: A review of the literature. Food Control 59, 178-187.

GUERRERO, L., GUARDIA, M.D., XICOLA, J., VERBEKE, W., VANHONACKER, F., ZAKOWSKA-BIEMANS, S., SAJDAKOWSKA, M., SULMONT-ROSSE', C., ISSANCHOU, S., CONTEL, M., SCALVEDI, M.L., SIGNE GRANLI, B. and HERSLETH, M. 2009. Consumerdriven definition of traditional food products and innovation in traditional foods. A qualitative cross-cultural study. Appetite 52, 345-354.

GUERRERO, L., CLARET, A., CHAYA, C., FERNÁNDEZ-RUIZ, V., ROMERO, E. \& VIEJO, J. 2012. La cultura del aceite de oliva en España. Fruticultura (Especial Olivicultura) 24, 106-111. 
406

407

408

409

410

411

412

413

414

415

416

417

418

419

420

421

422

423

424

425

426

427

428

429

430

431

HERSLETH, M., ILSENG, M.A., MARTENS, M. and NAES, T. 2005. Perception of cheese: a comparison of quality scoring, descriptive analysis and consumers responses. J. Food Qual. 28, 333-349.

IDF. 1997. Sensory evaluation of dairy products by scoring. IDF Standard 99C. International Dairy Federation. Brussels, Belgium.

ISO. 2005. Conformity assessment. General requirements for the competence of testing and calibration laboratories. ISO/IEC Standard 17025. International Organization for Standardization. Genève, Switzerland.

ISO. 2007. Sensory analysis - General guidance for the design of test rooms. ISO Standard 8589. International Organization for Standardization. Genève, Switzerland.

KRAGGERUD, H., SOLEM, S. and ABRAHAMSEN, R. 2012. Quality scoring - A tool for sensory evaluation of cheese?. Food Qual. Pref. 26, 221-230.

LIGGETT, R.E., DRAKE, M.A. and DELWICHE, J.F. 2008. Impact of flavor attributes on consumer liking of Swiss cheese. J. Dairy Sci. 91, 466-476.

MUÑOZ, A.M. 2002. Sensory evaluation in quality control: an overview, new developments and future opportunities. Food Qual. Pref. 13, 329-339.

OJEDA, M., ETAIO, I., FERNÁNDEZ GIL, M. P., ALBISU, M., SALMERÓN, J. and PÉREZ ELORTONDO, F.J. 2015. Sensory quality of cheese: going beyond the absence of defects. Food Control 51, 371-380.

ORDOÑEZ A.I., IBAÑEZ F.C., TORRE P., BARCINA Y. and PÉREZ ELORTONDO F.J. 1998. Application of multivariate analysis to sensory characterization of ewes' milk cheese. J. Sensory Stud. 13, 45-55.

PECORE, S. and KELLEN, L. 2002. A consumer-focused QC/sensory program in the food industry. Food Qual. Pref. 13, 369-374.

PÉREZ ELORTONDO F.J. 1996. Pasado y futuro del análisis sensorial del queso denominación de origen Idiazabal. Sustrai 40, 27-31. 
432

433

434

435

436

437

438

439

440

441

442

443

444

445

446

447

448

449

450

451

452

453

454

455

456

PÉREZ ElORTONDO, F. J., OJEDA, M., ALBiSU, M., SALMERON, J., ETAiO, I. and MOLINA, M. 2007. Food quality certification: an approach for the development of accredited sensory evaluation methods. Food Qual. Pref. 18, 425-439.

PÉREZ VILlARREAL, B., BARCINA ANGUlO, Y., PÉREZ DE CALlEJA, A., PÉREZ ELORTONDO, F.J., ZEBERIO TORRONTEGUI, M. and KELLEN, L. 1995. In Idiazabal: modo de empleo. pp. 69, Editorial gastronómika, Bilbao.

POELMAN, A.A.M., DELAHUNTY, C.M. and GRAAF, C. 2017. Vegetables and other core food groups: A comparison of key flavor and texture properties. Food Qual. Pref. 56,1-7.

PREACHER, K. J. 2001. Calculation for the chi-square test: An interactive calculation tool for chisquare tests of goodness of fit and independence [Computer software]. Available from http://quantpsy.org (last accessed December 20th, 2017).

PREDIERI, S., MEDORO, CH., MAGLI, M., GATTI, E. and ROTONDI, A. 2013. Virgin olive oil sensory properties: comparing trained panel evaluation and consumer preferences. Food Res. Int. 54, 2091-2094.

RECCHIA, A., MONTELEONE, E. and TOURILA, H. 2012. Responses to extra virgin olive oils in consumers with varying commitmeat to oils. Food Qual. Pref. 24, 153-161.

WORKU, M., DUCHATEAU, L. and BOECKX, P. 2016. Reproducibility of coffee quality cupping scores delivered by cupping centers in Ethiopia. J. Sensory Stud. 31, 423-429.

YATES, M.D. and DRAKE, M.A. 2007. Texture properties of Gouda cheese. J. Sensory Stud. 22, $493-506$.

YOUNG, N.D. DRAKE, M.A. LOPETCHARAT, K. and MCDANIELS M.R. 2004. Preference mapping of Cheedar cheese with varying maturity levels. J. Dairy Sci. 87, 9-11.

ZHANG, X.Y., GUO, H.Y., ZHAO, L., SUN, W.F., ZENG, S.S., LU, X.M., CAO, X. and REN, F.Z. 2011. Sensory profile and Beijing youth preference of seven cheese varieties. Food Qual. Pref. $22,101-109$. 
457

458

459

460

461

462

463

464

465

466

467

468

469

470

471

472

473

474

475

476

477

478

\section{Figure captions}

Figure 1. QUESTIONNAIRE TO MEASURE OBJECTIVE KNOWLEDGE.

Figure 2. INTERNAL PREFERENCE MAPPING OF CONSUMERS' DATA (N = 212) WITH INDICATION OF THE LEVEL OF CORRELATION BETWEEN THE INDIVIDUAL LIKING AND THE OSQ FROM THE TRAINED PANEL: Consumer with negative correlation in triangles (in black = medium-high correlation; in light grey $=$ low correlation) and consumers with positive correlation in circles (in black $=$ high correlation, in dark grey $=$ medium correlation, in light grey $=$ low correlation). High correlation: $r \geq 0.7$; medium correlation: $0.4 \leq r<0.7$; low correlation: $r<$ 0.4 .

Figure 3. REPRESENTATION OF THE SIGNIFICANT $(P<0.05)$ SENSORY CHARACTERISTICS FROM THE COCHRAN'S Q TEST AND THE CHEESE SAMPLES (N = 9) OVER THE FIRST TWO COMPONENTS FROM THE SIMPLE CORRESPONDENCE ANALYSIS. Appropriate characteristics in rhombus, not totally appropriate characteristics in circles and defective characteristics in triangles. $\mathrm{O}=$ odor; $\mathrm{Tx}=$ texture; $\mathrm{F}=$ flavor; $\mathrm{P}=$ persistence. _ns = null to slight intensity; _ $\mathrm{sm}=$ slight to medium intensity; _ $\mathrm{mh}=$ medium to high intensity; _ab = absence of; _w = weak; _m = medium intensity; $\_\mathrm{h}=$ high intensity; _v = very; $\mathrm{h} v \mathrm{~h}=$ high to very high intensity.

Figure 3 (color version) for color reproduction on the web and, Figure 3 (black and white version) to print.

Figure 4. PREFERENCE MAPPING FROM THE SIMPLE CORRESPONDENCE ANALYSIS WITH REPRESENTATION OF CHEESE SAMPLES AND THE VECTOR OF MAXIMUM PREFERENCE FOR EACH OF THE FIVE GROUPS OF CONSUMERS IDENTIFIED. 
479 TABLE 1. SOCIO-DEMOGRAPHIC CHARACTERISTICS AND CHEESE CONSUMPTION 480 HABITS OF PARTICIPANTS (DATA EXPRESSED AS NUMBER OF INDIVIDUALS AND, IN 481 BRACKETS, PERCENTAGE OVER THE WHOLE SAMPLE, (N=212).

\begin{tabular}{|c|c|}
\hline Socio-demographic characteristics & $\mathbf{N}$ \\
\hline \multicolumn{2}{|l|}{ Gender } \\
\hline Female & $112(52.8)$ \\
\hline Male & $100(47.2)$ \\
\hline \multicolumn{2}{|l|}{ Age } \\
\hline $18-29$ & $60(28.3)$ \\
\hline $30-44$ & $54(25.5)$ \\
\hline $45-59$ & $52(24.5)$ \\
\hline$\geq 60$ & $46(21.7)$ \\
\hline \multicolumn{2}{|l|}{ Education level } \\
\hline Primary school & $43(20.3)$ \\
\hline Secondary school & $44(20.7)$ \\
\hline Vocational Education and Training & $75(35.4)$ \\
\hline University & $50(23.6)$ \\
\hline \multicolumn{2}{|l|}{ Work situation } \\
\hline Student & $43(20.3)$ \\
\hline Unemployed & $55(25.9)$ \\
\hline Pensioner & $38(17.9)$ \\
\hline Worker & $76(35.9)$ \\
\hline \multicolumn{2}{|l|}{ Cheese consumption frequency } \\
\hline Daily or almost daily & $68(32.1)$ \\
\hline Once a week / several times a week & $109(51.4)$ \\
\hline Once a month / several times a month & $35(16.5)$ \\
\hline \multicolumn{2}{|l|}{ Type of cheese mostly consumed } \\
\hline Fresh soft cheese & $15(7.1)$ \\
\hline Semi-hard cheese & $64(30.2)$ \\
\hline Hard cheese & $120(56.6)$ \\
\hline No answer & $13(6.1)$ \\
\hline \multicolumn{2}{|l|}{ Origin of the milk of the cheese mostly } \\
\hline \multicolumn{2}{|l|}{ consumed } \\
\hline Cow & $40(18.9)$ \\
\hline Ewe / goat & $158(74.5)$ \\
\hline No answer & $14(6.6)$ \\
\hline
\end{tabular}


Subjective knowledge about cheese ${ }^{a}$

Low knowledge (score $\leq 2)$

Medium knowledge (score from 3 to 5) 164 (77.4)

High knowledge ( score $\geq 6)$

Objective knowledge about cheese ${ }^{\mathrm{b}}$

Very low knowledge (0 - 29 points) $92(43.4)$

Low knowledge (30 - 49 points) 82 (38.7)

Medium - high knowledge ( $\geq 50$ points) 38 (17.9)

$482{ }^{\mathrm{a}}$ Answer scale ranged from 1 (low knowledge) to 7 (high knowledge).

$483{ }^{\mathrm{b}}$ Grade from 0 to 100. 
484 TABLE 2. MEAN AND STANDARD DEVIATION (SD), FOR THE SENSORY PARAMETERS EVALUATED BY THE

485 TRAINED PANEL AND FOR CONSUMERS' LIKING FOR THE CHEESES.

\begin{tabular}{|c|c|c|c|c|c|c|c|c|c|c|c|c|}
\hline \multirow[b]{3}{*}{ Cheese } & \multicolumn{10}{|c|}{ Sensory parameters evaluated by the trained panel } & \multicolumn{2}{|c|}{ Liking from consumers } \\
\hline & \multicolumn{2}{|c|}{ Odor } & \multicolumn{2}{|c|}{ Texture } & \multicolumn{2}{|c|}{ Flavor } & \multicolumn{2}{|c|}{ Persistence } & \multicolumn{2}{|l|}{ OSQ } & & \\
\hline & Mean & $\mathbf{S D}^{\mathbf{a}}$ & Mean & $\mathbf{S D}^{\mathbf{a}}$ & Mean & $\mathbf{S D}^{\mathbf{a}}$ & Mean & $\mathbf{S D}^{\mathbf{a}}$ & Mean & $\mathbf{S D}^{\mathbf{a}}$ & Mean & SD \\
\hline 1 & $3.2 \mathrm{~cd}$ & 0.61 & $2.8 \mathrm{~d}$ & 0.64 & $2.6 \mathrm{~cd}$ & 0.53 & $2.5 \mathrm{c}$ & 0.53 & $2.7 \mathrm{e}$ & 0.50 & $5.2 \mathrm{e}$ & 1.98 \\
\hline 2 & $2.3 \mathrm{~d}$ & 1.14 & $3.9 \mathrm{abc}$ & 0.69 & $2.3 \mathrm{~d}$ & 0.87 & $2.3 \mathrm{c}$ & 1.04 & $2.7 \mathrm{e}$ & 0.74 & $5.0 \mathrm{e}$ & 1.95 \\
\hline 3 & $3.7 \mathrm{bcd}$ & 1.06 & $3.1 \mathrm{~cd}$ & 0.35 & $3.6 \mathrm{bcd}$ & 0.77 & $3.7 \mathrm{abc}$ & 0.64 & $3.5 \mathrm{~d}$ & 0.47 & $6.0 \mathrm{bcd}$ & 1.88 \\
\hline 4 & $4.1 \mathrm{bcd}$ & 0.79 & $3.6 \mathrm{bcd}$ & 0.91 & $3.8 \mathrm{abc}$ & 1.08 & $3.8 \mathrm{ab}$ & 1.01 & $3.8 \mathrm{~cd}$ & 0.82 & $5.7 \mathrm{~d}$ & 1.55 \\
\hline 5 & $4.3 \mathrm{abc}$ & 0.65 & $4.6 \mathrm{ab}$ & 0.53 & $3.4 \mathrm{bcd}$ & 0.92 & $3.4 \mathrm{bc}$ & 0.99 & $3.9 \mathrm{~cd}$ & 0.64 & $6.2 \mathrm{bcd}$ & 1.56 \\
\hline 6 & $4.3 \mathrm{abc}$ & 0.69 & $4.3 \mathrm{ab}$ & 0.49 & $4.1 \mathrm{ab}$ & 1.18 & $3.9 \mathrm{ab}$ & 0.88 & $4.2 \mathrm{bc}$ & 0.71 & $5.8 \mathrm{~cd}$ & 1.62 \\
\hline 7 & $4.5 \mathrm{ab}$ & 0.91 & $4.0 \mathrm{abc}$ & 0.46 & $4.4 \mathrm{ab}$ & 0.91 & $4.3 \mathrm{ab}$ & 0.80 & $4.3 \mathrm{abc}$ & 0.64 & $6.3 \mathrm{ab}$ & 1.47 \\
\hline 8 & $4.4 \mathrm{ab}$ & 0.92 & $4.7 \mathrm{a}$ & 0.83 & $4.6 \mathrm{ab}$ & 0.82 & $4.4 \mathrm{ab}$ & 0.74 & $4.5 \mathrm{ab}$ & 0.63 & $6.3 \mathrm{abc}$ & 1.57 \\
\hline 9 & $4.9 \mathrm{a}$ & 0.76 & $4.4 \mathrm{ab}$ & 0.75 & $4.9 \mathrm{a}$ & 0.59 & $4.8 \mathrm{a}$ & 0.69 & 4. $8 \mathrm{a}$ & 0.40 & $6.6 \mathrm{a}$ & 1.52 \\
\hline
\end{tabular}

486 Within a column, different letters indicate significant differences between cheese samples $(P<0.05)$ according to Dunn's

487 test and Tukey's HSD test.

$488{ }^{\mathrm{a}} \mathrm{SD}$ for trained panel was calculated as the mean score of SD of session 1 and SD of session 2. 
489 TABLE 3. MEAN LIKING SCORES PER SAMPLE AND GROUP OF CONSUMERS CATEGORIZED

490 ACCORDING TO THEIR PEARSON CORRELATION COEFFICIENT (r) BETWEEN OVERALL SENSORY

491 QUALITY (OSQ) AND INDIVIDUAL LIKING.

\begin{tabular}{|c|c|c|c|c|c|c|c|}
\hline \multirow[b]{3}{*}{ Cheese } & \multicolumn{3}{|c|}{ Negative correlation between liking and OSQ } & \multicolumn{4}{|c|}{ Positive correlation between liking and OSQ } \\
\hline & $\begin{array}{l}\text { High }^{\mathrm{a}} \text { and } \\
\text { Medium }^{\mathrm{b}}\end{array}$ & Low $^{c}$ & Global & Low & Medium & High & Global \\
\hline & $\begin{array}{l}\text { Group 1 } \\
(\mathrm{n}=16) \\
\end{array}$ & $(\mathrm{n}=32)$ & $\begin{array}{l}\text { Group } 2 \\
\quad(n=48)\end{array}$ & $\begin{array}{l}\text { Group } 3 \\
(\mathrm{n}=\mathbf{7 0})\end{array}$ & $\begin{array}{l}\text { Group } 4 \\
(n=52)\end{array}$ & $\begin{array}{l}\text { Group } 5 \\
(\mathrm{n}=42)\end{array}$ & $(n=164)$ \\
\hline 1 & $7.6 \mathrm{a}$ & 6.3 & $6.8 \mathrm{a}$ & $5.3 \mathrm{~d}$ & $4.6 \mathrm{de}$ & $4.1 \mathrm{e}$ & $4.8 \mathrm{~d}$ \\
\hline 2 & $6.6 \mathrm{ab}$ & 6.4 & $6.5 \mathrm{ab}$ & $5.3 \mathrm{~cd}$ & $4.3 \mathrm{e}$ & $3.4 \mathrm{e}$ & $4.5 \mathrm{~d}$ \\
\hline 3 & $7.1 \mathrm{a}$ & 6.4 & $6.6 \mathrm{a}$ & $6.1 \mathrm{abc}$ & $5.7 \mathrm{c}$ & $5.4 \mathrm{~d}$ & $5.8 \mathrm{c}$ \\
\hline 4 & $5.8 \mathrm{bc}$ & 5.6 & $5.7 \mathrm{bc}$ & 5.9 abcd & $5.4 \mathrm{~cd}$ & $5.9 \mathrm{~cd}$ & $5.7 \mathrm{c}$ \\
\hline 5 & $5.8 \mathrm{bc}$ & 6.4 & $6.2 \mathrm{abc}$ & $6.2 \mathrm{ab}$ & $6.0 \mathrm{bc}$ & $6.3 b c$ & $6.1 \mathrm{bc}$ \\
\hline 6 & $5.6 \mathrm{c}$ & 5.9 & $5.8 \mathrm{bc}$ & $5.6 \mathrm{bcd}$ & $5.9 \mathrm{bc}$ & $6.2 \mathrm{bc}$ & $5.9 \mathrm{c}$ \\
\hline 7 & $6.0 \mathrm{bc}$ & 6.0 & $6.0 \mathrm{abc}$ & $6.1 \mathrm{abc}$ & $6.5 \mathrm{ab}$ & $6.8 \mathrm{ab}$ & $6.4 \mathrm{ab}$ \\
\hline 8 & $5.6 \mathrm{bc}$ & 5.5 & $5.6 \mathrm{c}$ & $6.1 \mathrm{abcd}$ & $6.6 \mathrm{ab}$ & $7.0 \mathrm{a}$ & $6.5 \mathrm{ab}$ \\
\hline 9 & $5.3 \mathrm{c}$ & 5.8 & $5.7 \mathrm{c}$ & $6.5 \mathrm{a}$ & $7.0 \mathrm{a}$ & $7.5 \mathrm{a}$ & $6.9 \mathrm{a}$ \\
\hline
\end{tabular}

492 Within a column, different lower case letters represent significant differences $(P<0.05)$ between samples according to Tukey's HSD test.

$493{ }^{\mathrm{a}} \mathrm{r} \geq 0.7$

$494 \quad{ }^{\mathrm{b}} 0.4 \leq \mathrm{r}<0.7$

$495{ }^{\mathrm{c}} \mathrm{r}<0.4$ 
Please, mark only one answer for each question:

1. Mark the origin of the milk for each kind of cheese:

\begin{tabular}{|c|c|c|c|}
\hline Cheese & \multicolumn{3}{|c|}{ Origin of the milk } \\
\hline Gouda & Cow $\square$ & Ewe $\square$ & I do not know $\square$ \\
\hline Idiazabal & Cow $\square$ & Ewe $\square$ & I do not know $\square$ \\
\hline Camembert & Cow $\square$ & Ewe $\square$ & I do not know $\square$ \\
\hline Gorgonzola & Cow $\square$ & Ewe $\square$ & I do not know $\square$ \\
\hline Manchego & Cow $\square$ & Ewe $\square$ & I do not know $\square$ \\
\hline
\end{tabular}

2. Which of the following cheeses has usually the rind covered by a mould layer?
1. Cheddar
2. Manchego
3. Camembert
4. Parmesan

5. I do not know

3. Which of the following cheeses is traditionally made with buffalo's milk?
1. Feta
2. Gorgonzola
3. Parmesan
4. Mozzarella
5. I do not know

4. What is the rennet?
1. It is the product resulting from the coagulation of the milk proteins
2. It is a preparation with enzymes from animal origin, from vegetal origin or from mould origin
3. The bacteria that are added to the milk so that it ferments
4. A technological operation feature of "white paste cheeses"
5. I do not know

5. Which are the usual mechanisms to coagulate the milk?
1. The addition of bacteria and the addition of enzymes
2. Applying high temperature combined with milkshake
3. The addition of salt
4. The addition of acetic acid
5. I do not know

6. Which ewe's breed does the milk used for making Idiazabal cheese come from?
1. Latxa and Merina
2. Assaf
3. Latxa and Carranzana
4. Hampshire and Churra
5. I do not know

7. What is the characteristic mould of the Roquefort cheese?
1. Penicillium
2. Acid-lactic bacteria
3. Acetobacter
4. Aspergillus
5. I do not know

8. Which of the following cheeses has a very hard texture?
1. Gruyere
2. Edam
3. Brie
4. Parmesan
5. I do not know

9. Which country is Edam cheese related to?
1. England
2. Greece
3. Italy
4. Netherlands
5. I do not know

10. Which of the following cheeses has big and round holes?
1. Parmesan
2. Cheddar
3. Emmental
4. Manchego
5. I do not know 


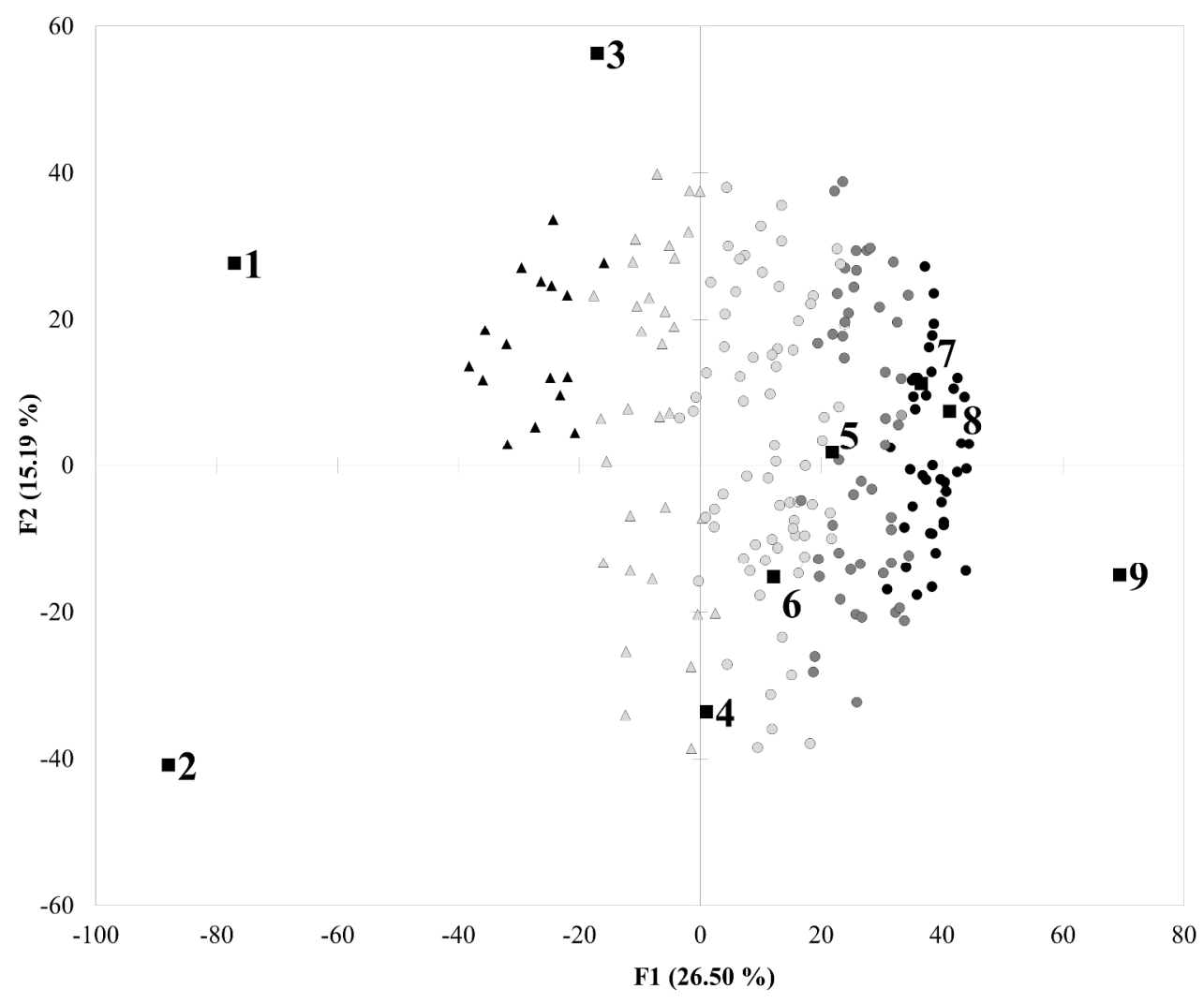

Figure 2. INTERNAL PREFERENCE MAPPING OF CONSUMERS' DATA $(N=212)$ WITH INDICATION OF THE LEVEL OF CORRELATION BETWEEN THE INDIVIDUAL LIKING AND THE OSQ FROM THE TRAINED PANEL: Consumer with negative correlation in triangles (in black = medium-high correlation; in light grey = low correlation) and consumers with positive correlation in circles (in black = high correlation, in dark grey = medium correlation, in light grey $=$ low correlation). High correlation: $r \geq 0.7$; medium correlation: $0.4 \leq r$ $<0.7$; low correlation: $r<0.4$.

$1009 \times 869 \mathrm{~mm}(96 \times 96 \mathrm{DPI})$ 


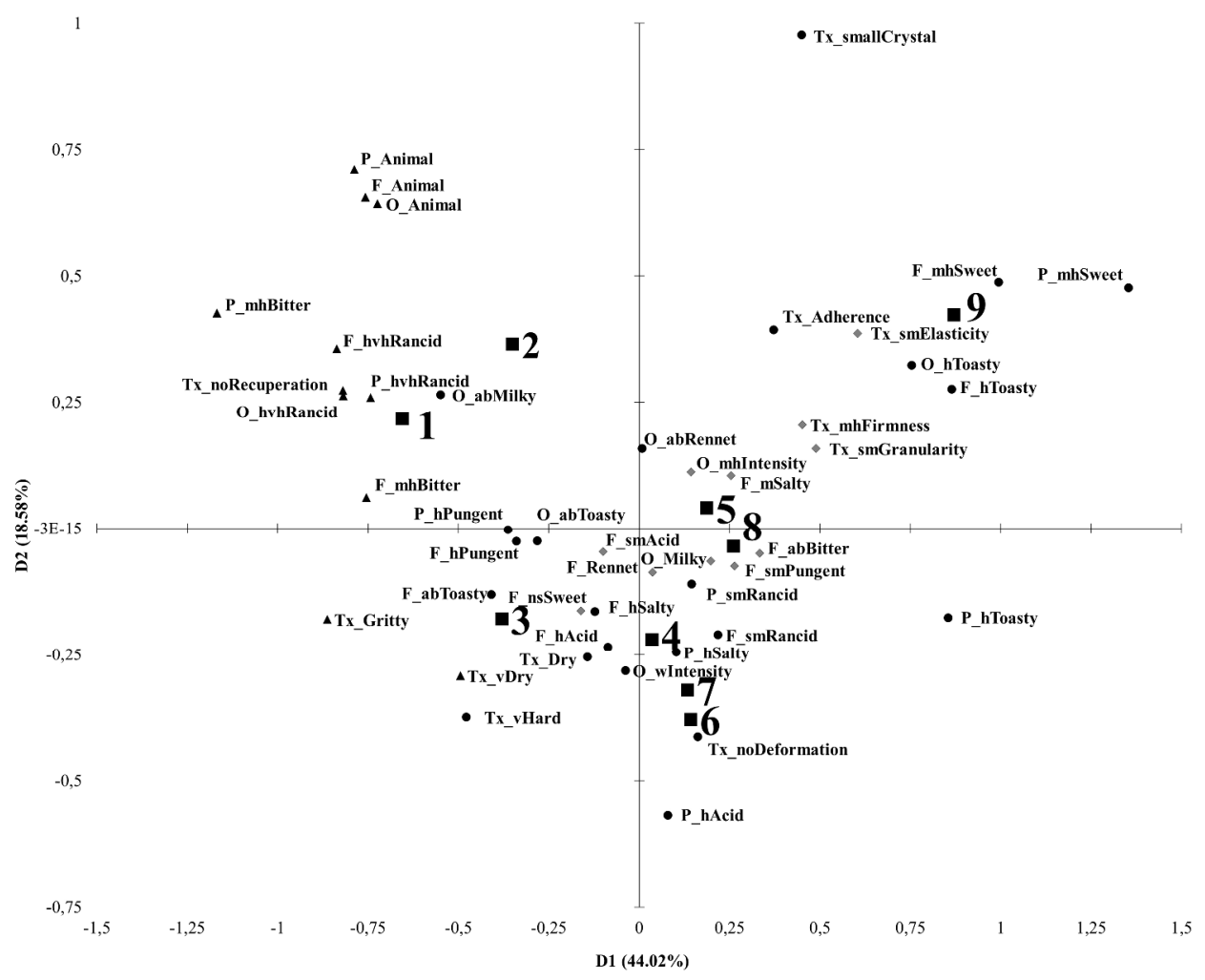

Figure 3. REPRESENTATION OF THE SIGNIFICANT $(P<0.05)$ SENSORY CHARACTERISTICS FROM THE COCHRAN'S Q TEST AND THE CHEESE SAMPLES $(N=9)$ OVER THE FIRST TWO COMPONENTS FROM THE SIMPLE CORRESPONDENCE ANALYSIS. Appropriate characteristics in rhombus, not totally appropriate characteristics in circles and defective characteristics in triangles. $\mathrm{O}=$ odor; $\mathrm{Tx}=$ texture; $\mathrm{F}=$ flavor; $\mathrm{P}=$ persistence. _ns = null to slight intensity; $\_\mathrm{sm}=$ slight to medium intensity; $\_\mathrm{mh}=$ medium to high intensity;_ab = absence of;_ $\mathrm{w}=$ weak;_m = medium intensity; _ $\mathrm{h}=$ high intensity; _v = very;_hvh = high to very high intensity.

$1009 \times 869 \mathrm{~mm}(96 \times 96 \mathrm{DPI})$ 


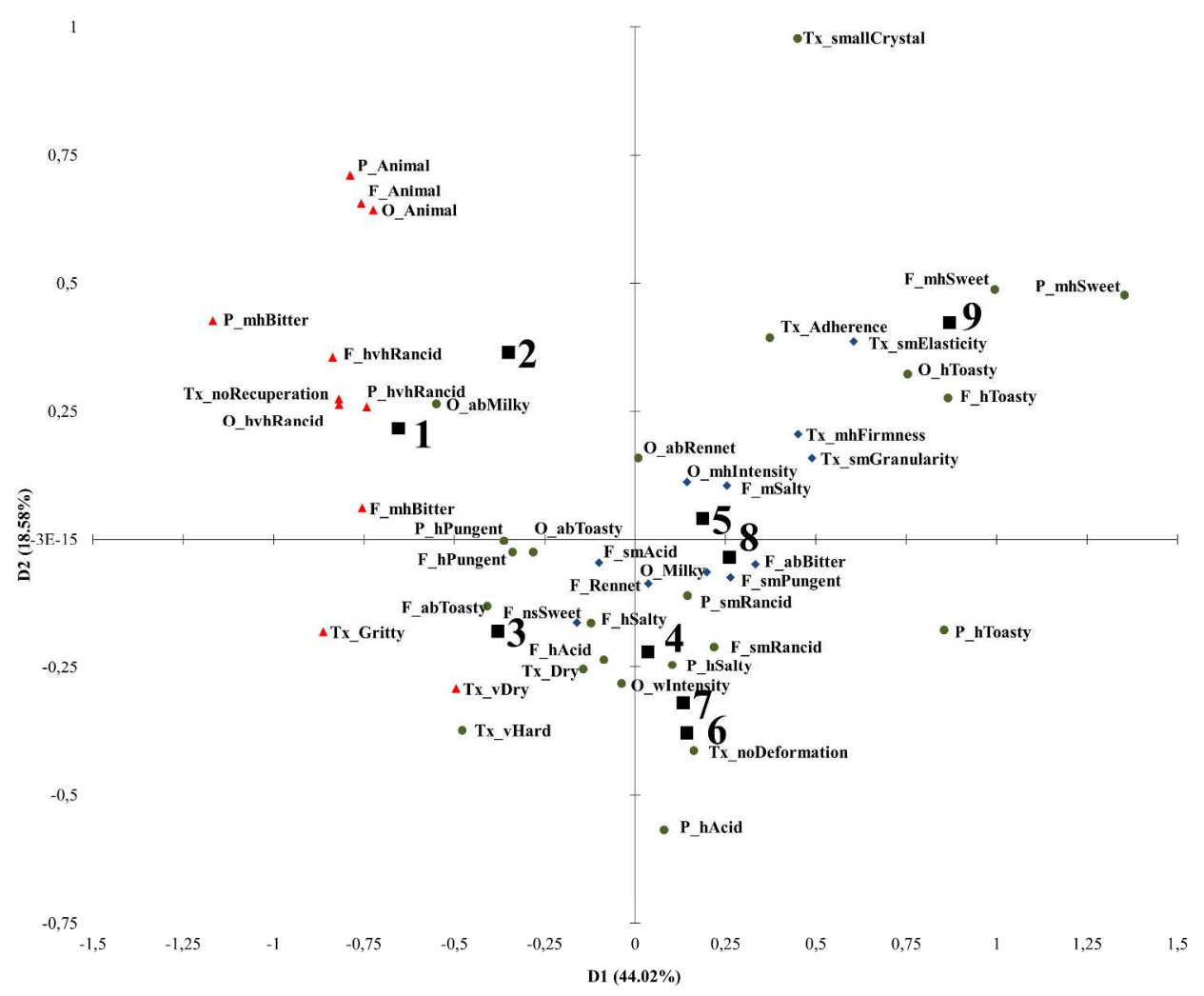

Figure 3. REPRESENTATION OF THE SIGNIFICANT $(P<0.05)$ SENSORY CHARACTERISTICS FROM THE COCHRAN'S Q TEST AND THE CHEESE SAMPLES $(N=9)$ OVER THE FIRST TWO COMPONENTS FROM THE SIMPLE CORRESPONDENCE ANALYSIS. Appropriate characteristics in rhombus, not totally appropriate characteristics in circles and defective characteristics in triangles. $\mathrm{O}=$ odor; $\mathrm{Tx}=$ texture; $\mathrm{F}=$ flavor; $\mathrm{P}=$ persistence. _ns = null to slight intensity; $\_\mathrm{sm}=$ slight to medium intensity; $\_\mathrm{mh}=$ medium to high intensity;_ab = absence of;_ $\mathrm{w}=$ weak;_m = medium intensity; _ $\mathrm{h}=$ high intensity; _v = very;_hvh = high to very high intensity.

$1009 \times 869 \mathrm{~mm}(96 \times 96 \mathrm{DPI})$ 


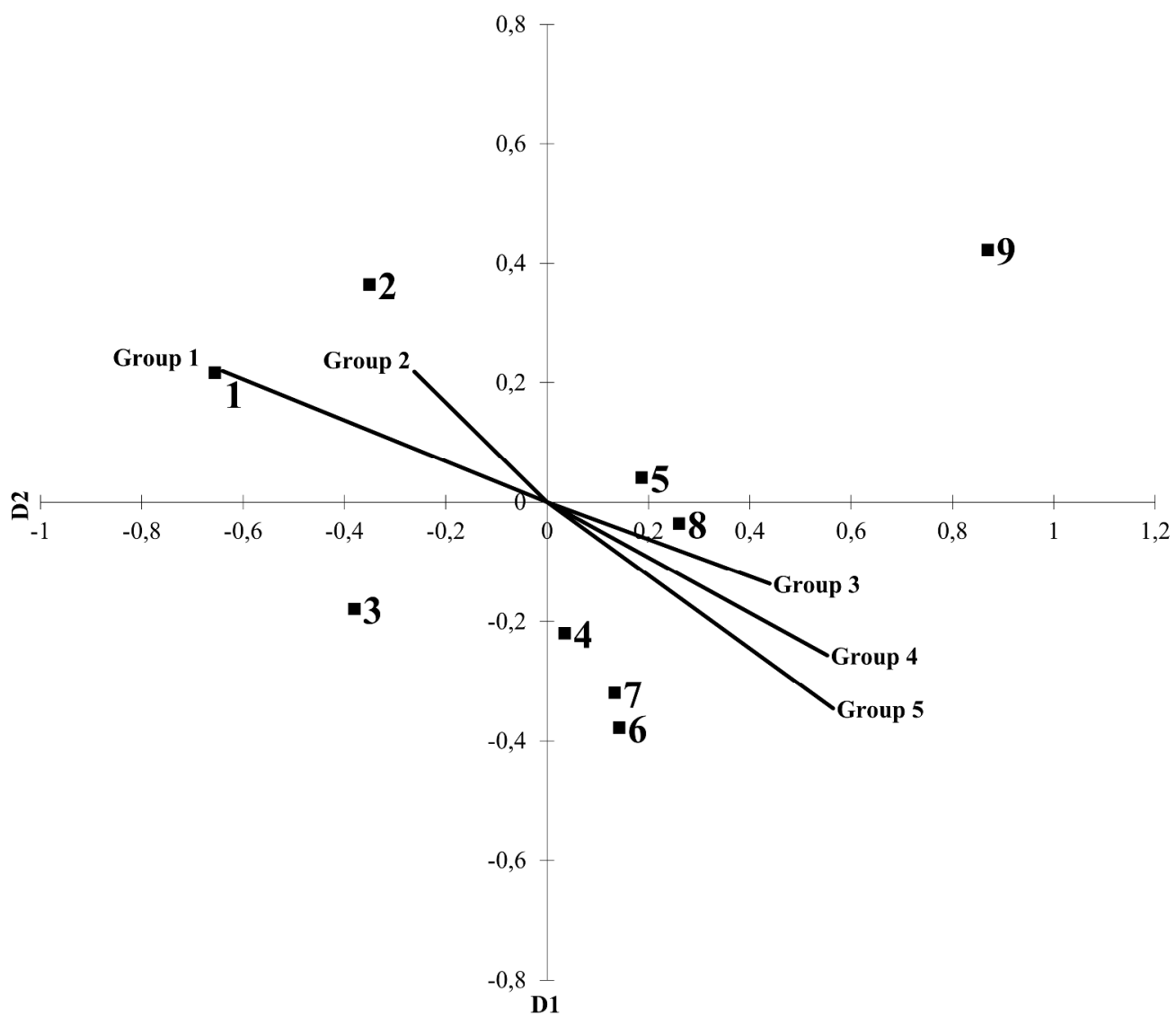

Figure 4. PREFERENCE MAPPING FROM THE SIMPLE CORRESPONDENCE ANALYSIS WITH REPRESENTATION OF CHEESE SAMPLES AND THE VECTOR OF MAXIMUM PREFERENCE FOR EACH OF THE FIVE GROUPS OF CONSUMERS IDENTIFIED.

$1009 \times 869 \mathrm{~mm}(96 \times 96 \mathrm{DPI})$ 